\title{
Stock discrimination of pilchards Sardinops sagax by stable isotope ratio analysis of otolith carbonate
}

\author{
J. S. Edmonds*, W. J. Fletcher** \\ Western Australian Marine Research Laboratories, PO Box 20, North Beach, Western Australia 6020, Australia
}

\begin{abstract}
Measurement of the ratios of the stable isotopes ${ }^{18} \mathrm{O}:{ }^{16} \mathrm{O}$ and ${ }^{13} \mathrm{C}:{ }^{12} \mathrm{C}$, by standard mass spectrometric techniques, in the otolith carbonate of samples of pilchards Sardinops sagax from coastal waters adjacent to the 4 main fishing ports of southwestern Australia (Fremantle, Albany, Bremer Bay and Esperance) provided location-specific signatures which showed that Fremantle fish could be regarded as a separate stock from those taken at the other 3 locations, and fish from Esperance constituted a different stock from those fish taken at Albany and Bremer Bay. The isotope signatures for fish from the different locations persisted through time, and it could be concluded that they comprised separate stocks for most of the purposes of fisheries management. Values for ratios of stable oxygen isotopes in pilchard otolith carbonate indicated that they were probably deposited close to equilibrium and therefore reflected ambient water temperatures as governed by latitude and movements of the Leeuwin Current. This suggested that the measurement of ratios of stable oxygen isotopes can be a valuable method for the discrimination of management units of adult fish where the range of distribution of a species covers waters of different temperatures.
\end{abstract}

KEY WORDS: Stock discrimination S Stable isotopes - Otolith carbonate Sardinops sagax - Western Australia

\section{INTRODUCTION}

The fisheries for pilchards Sardinops sagax in Western Australia are centred at the ports of Fremantle on the west coast, and Albany, Bremer Bay and Esperance on the south coast (Fig. 1). With fishing effort largely restricted to the waters adjacent to each of the ports of operation, the fisheries are naturally divided into 4 areas, along with the more general division of west and south coast fisheries. To implement effective management strategies for the sustainable exploitation of pilchard stocks off southwestern Australia (by, for example, the control of fishing effort), there is a need to know whether the overall distribution of the species in the region should be regarded as a single stock or whether there are a number of smaller, essentially non-mixing population units. In this paper 'stocks' refers to groups

\footnotetext{
-E-mail joedmonds@fish.wa.gov.au

- Present address: New South Wales Fisheries Research lnstitute, PO Box 21, Cronulla, New South Wales 2230, Australia
}

of post-juvenile fish that remain separate and non-mixing. It does not imply that such groups of fish constitute separate breeding populations.

A previous attempt to discriminate between pilchards caught in the several locations in southwestern Australia, and thereby to define non-mixing groups of adult fish, by microchemical analysis of otoliths produced results that were difficult to interpret (Edmonds et al. 1995). The isotope study reported here was undertaken to help determine the degree of separation between the pilchard stocks in each of the areas. We anticipated that by measuring the ratios of the stable isotopes of oxygen and carbon in the otolith carbonate, i.e. properties of the bulk material of the otoliths, we would avoid the difficulties encountered in the interpretation of trace analysis (which involved the measurement of elements that might be thought to have been adventitiously acquired and thereby potentially subject to short-term variation).

Previous studies of stable isotope ratios in the carbonate from teleost otoliths have shown that oxygen 


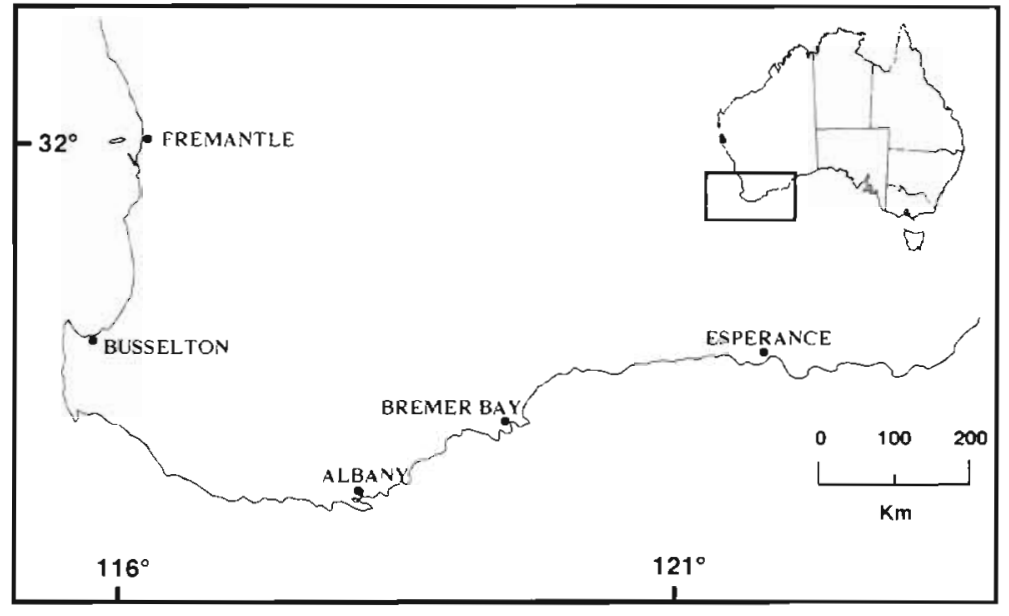

Fig. 1 Sampling locations corresponding to the major fishing ports for pilchards in southwestern Australia

isotopes are probably deposited at or close to equilibrium with ambient seawater (Devereux 1967, Degens et al. 1969, Kalish 1991a, b, Iacumin et al. 1992). Known differences in the average sea temperatures between the locations where fishing occurs should therefore provide the basis for differences in oxygen isotopic compositions if the stocks are separate.

Stable carbon isotopes in otolith carbonate are not deposited in equilibrium with ambient seawater (Degens et al. 1969, Mulcahy et al. 1979, Kalish 1991b).
Kalish (1991b) developed the argument for the importance of metabolic effects in mediating ${ }^{13} \mathrm{C}$ disequilibria in otolith carbonate and rationalised the reported range of $\delta^{13} \mathrm{C}$ values both within species and between species on the basis of metabolic rates. Strong correlations between $\delta^{13} \mathrm{C}$ and temperature and accompanying strong correlations between $\delta^{13} \mathrm{C}$ and $\delta^{18} \mathrm{O}$ have been found for interspecific comparisons (Kalish 1991b), but they were weak or absent when a single species (Australian salmon Arripis truttaceous) was examined (Kalish 1991a)

The isotope experiments were therefore designed to reveal whether the isotope signatures of the pilchard otolith carbonate differed from location to location and, if they did, whether these differences persisted through time. If both of these conditions were fulfilled for any or all of the groups of fish examined, it could be assumed that they comprised separate units for fisheries management purposes.

\section{METHODS}

A preliminary experiment was carried out on samples of pilchards caught in December 1991 to deter-

Table 1. Sardinops sagax. Summary of sampling programme and results for $\delta^{13} \mathrm{C}$ and $\delta^{18} \mathrm{O}$ analyses of otolith carbonate

\begin{tabular}{|c|c|c|c|c|c|c|}
\hline Location & Date & $\begin{array}{l}\text { No. of } \\
\text { samples }\end{array}$ & $\begin{array}{l}\text { No. of otoliths } \\
\text { per sample (range) }\end{array}$ & $\begin{array}{l}\text { Otolith weight } \\
\text { range (mg) }\end{array}$ & $\begin{array}{l}\delta^{13} \mathrm{C}(\% \mathrm{PDB}) \\
\text { mean and range }\end{array}$ & $\begin{array}{c}\delta^{18} \mathrm{O}(\% \mathrm{PDB}) \\
\text { mean and range }\end{array}$ \\
\hline Fremantle & $\begin{array}{r}\text { Dec } 1991 \\
\text { Mar/Apr } 1993 \\
\text { Jun/Jul } 1993 \\
\text { Sep/Nov } 1993 \\
\text { Jan/Feb } 1994\end{array}$ & $\begin{array}{r}10 \\
20 \\
27 \\
10 \\
8\end{array}$ & $\begin{array}{r}8-13 \\
8-17 \\
8-20 \\
10-19 \\
12-20\end{array}$ & $\begin{array}{l}1.00-2.30 \\
1.11-2.26 \\
1.25-2.27 \\
1.29-2.33 \\
1.14-2.22\end{array}$ & $\begin{array}{l}-6.89(-7.09 \text { to }-6.62) \\
-7.05(-7.34 \text { to }-6.73) \\
-7.09(-7.48 \text { to }-6.80) \\
-7.03(-7.23 \text { to }-6.58) \\
-7.00(-7.17 \text { to }-6.69)\end{array}$ & $\begin{array}{l}0.77(0.54-0.99) \\
0.88(0.50-1.13) \\
0.66(0.37-0.80) \\
0.60(0.51-0.69) \\
0.65(0.51-0.77)\end{array}$ \\
\hline Busselton & $\begin{array}{l}\text { Oct } 1993 \\
\text { Jan } 1994\end{array}$ & $\begin{array}{l}12 \\
12\end{array}$ & $\begin{array}{l}12-20 \\
11-20\end{array}$ & $\begin{array}{l}1.35-2.42 \\
1.06-2.40\end{array}$ & $\begin{array}{l}-6.88(-7.14 \text { to }-6.57) \\
-6.91(-7.01 \text { to }-6.59)\end{array}$ & $\begin{array}{l}0.84(0.67-1.02) \\
0.77(0.70-0.85)\end{array}$ \\
\hline Albany & $\begin{array}{r}\text { Dec } 1991 \\
\text { Mar/Apr } 1993 \\
\text { Jun/Jul } 1993 \\
\text { Sept/Oct } 1993 \\
\text { Jan/Feb } 1994\end{array}$ & $\begin{array}{l}10 \\
24 \\
25 \\
44 \\
10\end{array}$ & $\begin{array}{r}8-13 \\
9-16 \\
11-18 \\
9-16 \\
8-16\end{array}$ & $\begin{array}{l}1.17-2.28 \\
1.00-2.17 \\
1.07-2.43 \\
1.02-2.44 \\
0.96-2.65\end{array}$ & $\begin{array}{l}-6.73(-7.06 \text { to }-6.53) \\
-7.1 .3(-7.57 \text { to }-6.55) \\
-6.87(-7.21 \text { to }-6.43) \\
-6.84(-7.29 \text { to }-6.43) \\
-6.77(-7.18 \text { to }-6.31)\end{array}$ & $\begin{array}{l}1.05(0.72-1.55) \\
0.91(0.18-1.24) \\
0.96(0.75-1.17) \\
0.88(0.54-1.18) \\
0.98(0.85-1.13)\end{array}$ \\
\hline Bremer Bay & $\begin{array}{r}\text { Dec } 1991 \\
\text { Mar/Apr } 1993 \\
\text { Jun/Jul } 1993 \\
\text { Sept/Oct } 1993 \\
\text { Jan/Feb } 1994\end{array}$ & $\begin{array}{l}10 \\
21 \\
30 \\
28 \\
11\end{array}$ & $\begin{array}{r}7-14 \\
9-16 \\
11-16 \\
12-16 \\
11-16\end{array}$ & $\begin{array}{l}0.91-2.57 \\
1.13-2.53 \\
1.01-2.50 \\
0.97-2.35 \\
1.12-2.37\end{array}$ & $\begin{array}{l}-6.64(-6.94 \text { to }-6.16) \\
-6.83(-7.39 \text { to }-6.25) \\
-6.78(-7.16 \text { to }-6.42) \\
-6.79(-7.09 \text { to }-6.50) \\
-6.90(-7.21 \text { to }-6.64)\end{array}$ & $\begin{array}{l}1.10(0.44-1.40) \\
0.91(0.58-1.23) \\
1.00(0.26-1.23) \\
1.00(0.88-1.14) \\
0.92(0.80-0.99)\end{array}$ \\
\hline Esperance & $\begin{array}{r}\text { Dec } 1991 \\
\text { Mar/Apr } 1993 \\
\text { Jun/Jul } 1993 \\
\text { Oct/Nov } 1993 \\
\text { Dec } 1993 / \text { Jan } 1994\end{array}$ & $\begin{array}{l}10 \\
19 \\
28 \\
18 \\
16\end{array}$ & $\begin{array}{r}8-18 \\
7-15 \\
10-16 \\
12-17 \\
9-18\end{array}$ & $\begin{array}{l}0.61-2.06 \\
0.99-2.73 \\
1.02-2.79 \\
1.03-2.24 \\
1.17-2.75\end{array}$ & $\begin{array}{l}-7.32(-7.65 \text { to }-6.88) \\
-6.77(-7.06 \text { to }-6.47) \\
-6.59(-6.88 \text { to }-6.40) \\
-6.91(-7.27 \text { to }-6.57) \\
-6.88(-7.30 \text { to }-6.59)\end{array}$ & $\begin{array}{l}0.96(0.70-1.12) \\
1.26(0.94-1.49) \\
1.07(0.79-1.27) \\
1.05(0.87-1.15) \\
1.02(0.94-1.10)\end{array}$ \\
\hline
\end{tabular}


mine if a full-scale study was warranted. The results of this first examination suggested that that there were indeed differences in oxygen isotope signatures between locations and that a full-scale study was necessary to confirm this initial observation and, most importantly, to determine if the differences persisted through time. Details of this preliminary study are included in Table 1, which shows the nature of the sampling programme as well as a summary of results, and results from the preliminary study are included in all statistical treatments.

Sampling was designed so that pilchards would be collected from commercial catches made at Fremantle, Albany, Bremer Bay and Esperance at 3 mo intervals through a single year, March, June, September and December 1993. Because of availability, otoliths from pilchards obtained at an additional west coast site (Busselton) were included for the final 2 sampling occasions, and there were some small adjustments to dates of sampling (Table 1 ).

Approximately 20 samples of the calcium carbonate from the pooled, powdered sagittal otoliths of several fish (the exact number depending on otolith weight) were deproteinated by treatment with hydrogen peroxide and analysed for ${ }^{18} \mathrm{O}:{ }^{16} \mathrm{O}$ and ${ }^{13} \mathrm{C}:{ }^{12} \mathrm{C}$ ratios by standard mass spectrometric techniques (CSIRO Division of Water Resources, Perth) for each of the 4 (5) locations and for each of the specified sampling times (Table 1). Values are reported in standard $\delta$ notation relative to the PDB-1 standard (Epstein et al. 1953).

To ensure that the total sample was representative of the area during a sampling period, the fish selected came from a number of different boats and were caught on different days within that period. Pooling of otoliths to form each sample was necessary because of the small size of pilchard otoliths (usually less than $2 \mathrm{mg}$ ) and the need for several $\mathrm{mg}$ of deproteinated carbonate for analysis. Pooling was done on the basis of otolith size (Table 1) for each school of fish sampled. Otolith weight is a good predictor of age for pilchards (Fletcher 1995), and based on otolith weight, the fish in this study ranged from 2 to $8 \mathrm{yr}$ with a mean of $\sim 4.5 \mathrm{yr}$. Where mean weights are referred to (i.e. Table 1 and Figs. 3 \& 4) these have been weighted to take the different sizes of the otoliths comprising each pooled group into account.

By separately examining samples derived from the various schools within the sampling area and period, we could ensure that any observed differences in isotopic signatures were really representative of the area and did not have the potential to merely reflect school-to-school differences.

To implement effective management strategies for the south coast pilchard fishery, there was a particular need to know whether fish taken at Bremer Bay could be regarded as a separate stock from those landed through Albany. A separate analysis of covariance was therefore carried out for these 2 locations only.

The relationship between measured values of $\delta^{18} \mathrm{O}:{ }^{15} \mathrm{O}$ and water temperature was explored by using sea surface temperatures derived as described by Reynolds \& Smith (1994).

\section{RESULTS}

Results are summarized in Table 1 and Figs. 2 to 6. Analysis of covariance (ANCOVA) showed that $46 \%$ of the sum of squares for $\delta^{18} \mathrm{O}$ values was explained by the main effects of location, otolith weight, and date of sampling. Of this, $36 \%$ was explained by location, $6 \%$ by otolith weight, and $4 \%$ by the date of capture, with the variables entered in this order (Table 2). A further $11 \%$ of the sum of squares was explained by interactions of otolith weight and location $(1 \%, p=0.06)$, otolith weight and date $(4 \%, \mathrm{p}=0.0001)$, and location and date $(6 \%, \mathrm{p}=0.0001)$.

For $\delta^{13} \mathrm{C}$ values $45 \%$ of the sum of squares was explained by location, otolith weight and date of capture, but in this case $13 \%$ was explained by location, $29 \%$ by otolith weight, and $3 \%$ by date of capture (Table 3). An additional $12 \%$ of the sum of squares was explained by interactions of otolith weight and location $(3 \%, p=0.0001)$, otolith weight and date $(2 \%, p=$ $0.0006)$, and location and date $(7 \%, p=0.0001)$. Examination of the slopes for the relationships between $\delta^{13} \mathrm{C}$

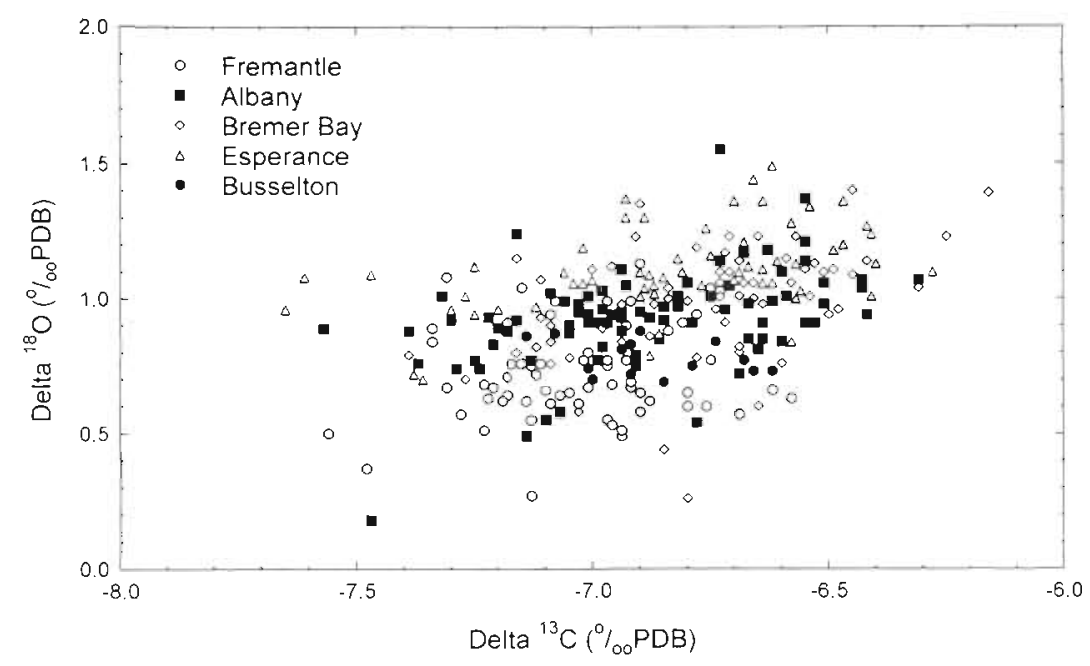

Fig. 2. $\delta^{18} \mathrm{O}$ vs $\delta^{13} \mathrm{C}$ for sagittal otolith carbonate for pilchards from all locations 


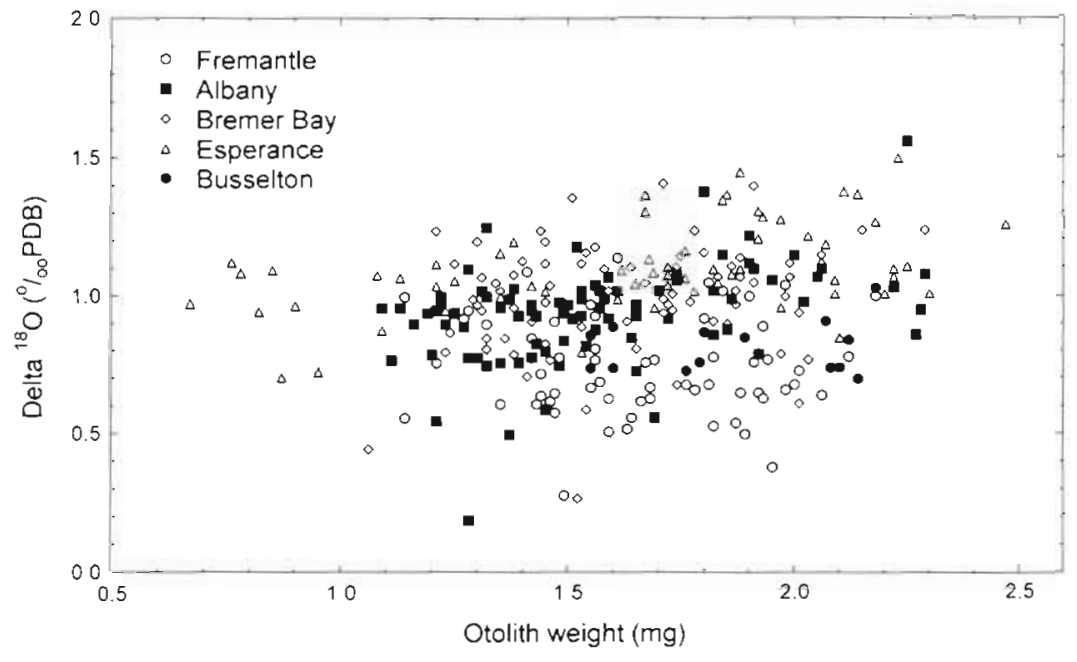

Fig. $3 \cdot \delta^{18} \mathrm{O}$ vs weighted mean otolith weight for all data

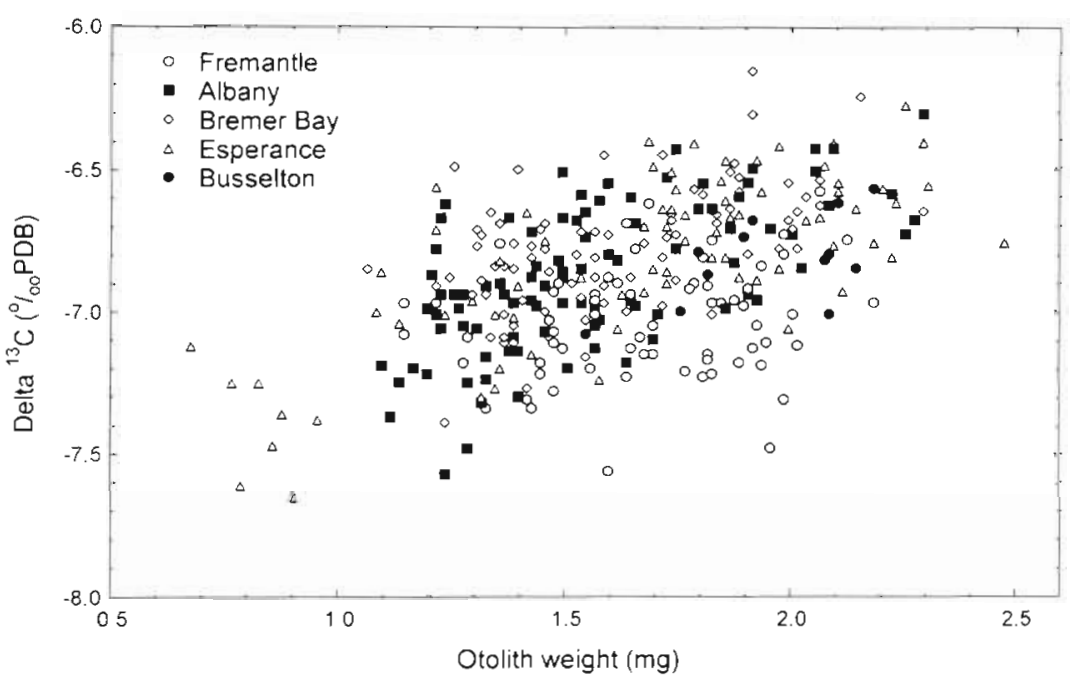

mantle) were, as expected, different from south coast fish, but results also suggested that they may constitute a separate stock from those from Fremantle. The independent analysis conducted on fish from Albany and Bremer Bay showed a significant difference $(p=0.005$, when otolith weight and date were taken into account) in $\delta^{13} \mathrm{C}$ values for the 2 locations, but no significant difference was observed for $\delta^{18} \mathrm{O}(\mathrm{p}=0.1)$.

An overall $\delta^{18} \mathrm{O}$ value for each location was calculated by taking the mean of the means for each sampling period, and these were plotted (Fig. 5) against the mean of the annual sea surface temperatures for the years 1989 to 1995 (see Reynolds \& Smith 1994) for the 5 locations (Busselton was included). The annual mean sea surface temperatures for 1989 to 1995 were the average of the 12 monthly means in each of the 7 years (Reynolds \& Smith 1994). A least-squares linear regression showed the relationship between $\delta^{18} \mathrm{O}$ and temperature to be: $\delta^{18} \mathrm{O}=3.2-0.12\left(T^{\circ} \mathrm{C}\right)$, with a correlation coefficient of -0.95 .

A plot of mean annual sea surface temperatures (Reynolds \& Smith 1994) against year for the years 1989 to 1995 is shown in Fig. 7 with an inverted scale for temperature to allow a comparison with $\delta^{18} \mathrm{O}$ data plotted by year (Fig. 6).

Fig. $4 . \delta^{13} \mathrm{C}$ vs weighted mean otolith weight for all data

and otolith weight for the several locations revealed that $\delta^{13} \mathrm{C}$ values for west coast fish (Fremantle and Busselton), with gradients of $\sim 0.2$, were increasing with otolith size at a slower rate than for south coast locations (Albany, Bremer Bay and Esperance), which had gradients of 0.3 to 0.56 .

ANCOVA for oxygen supported the observation, evident from the plots of oxygen isotope ratios (Fig. 6), that location of capture is the most important source of difference between the measured values. Thus, Fremantle fish, which had the lowest ratios, probably constitute a separate stock from fish taken on the south coast; in addition, fish from Esperance, which had the highest ratios, appear to be part of a different stock from those taken at Albany and Bremer Bay. Fish caught at Busselton (on the west coast but south of Fre-

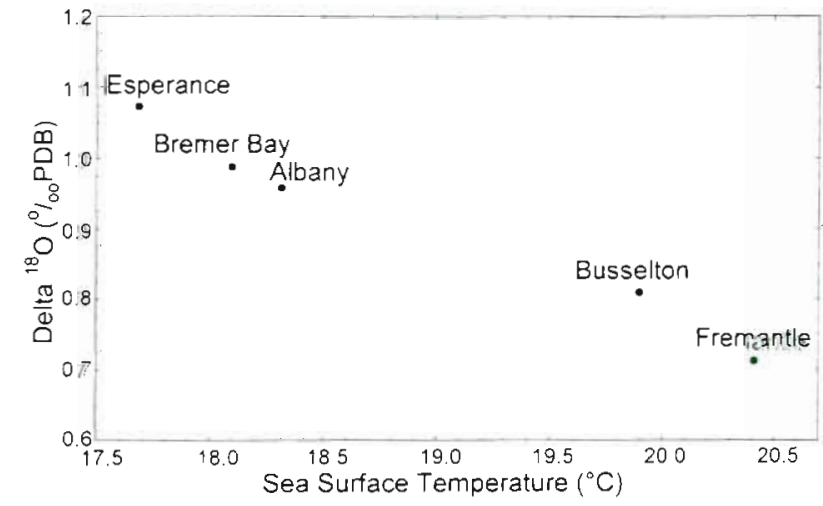

Fig. 5. Mean $\delta^{18} \mathrm{O}$ for each location vs mean sea surface temperatures (see Reynolds \& Smith 1994) for nach location for the years 1989 to 1995 inclusive. A least-squares linear regression for the data gives $\delta^{18} \mathrm{O}=3.2-0.12\left(T^{\circ} \mathrm{C}\right)$ 


\section{DISCUSSION}

Oxygen isotopes in otolith carbonate have been reported to be deposited in equilibrium with ambient seawater (Devereux 1967, Degens et al. 1969, Kalish 1991a, b, Iacumin et al. 1992) and their ratios are a function of water temperature. We anticipated, then, that any differences in oxygen isotope signatures for the 4 (5) locations could be explained by water temperature differences governed by latitude and possibly also by the extent of influence of the Leeuwin Current, which delivers, discontinuously and to varying extents, warm tropical water to the southern west coast and western south coast of Australia (Caputi et al. 1996). The pattern for the differences in ratios was therefore consistent with this hypothesis, with the lowest values, indicating the highest temperatures, found in otoliths of fish from Fremantle, the warmest location. Conversely, the highest ratios, indicating the coolest water, were measured in fish from Esperance, the coolest location. On the other hand, the observation that otolith weight is significantly correlated with $\delta^{18} \mathrm{O}$ measurements $6 \%$ of the sum of squares could be explained by otolith weight; Table 2) suggested either that oxygen isotopes are not deposited in equilibrium with ambient seawater in all circumstances, or that larger fish occupy colder waters than do smaller fish. Nevertheless, the differences in the stable oxygen isotope signatures for the otolith carbonate for populations of pilchards from locations around the south-west of

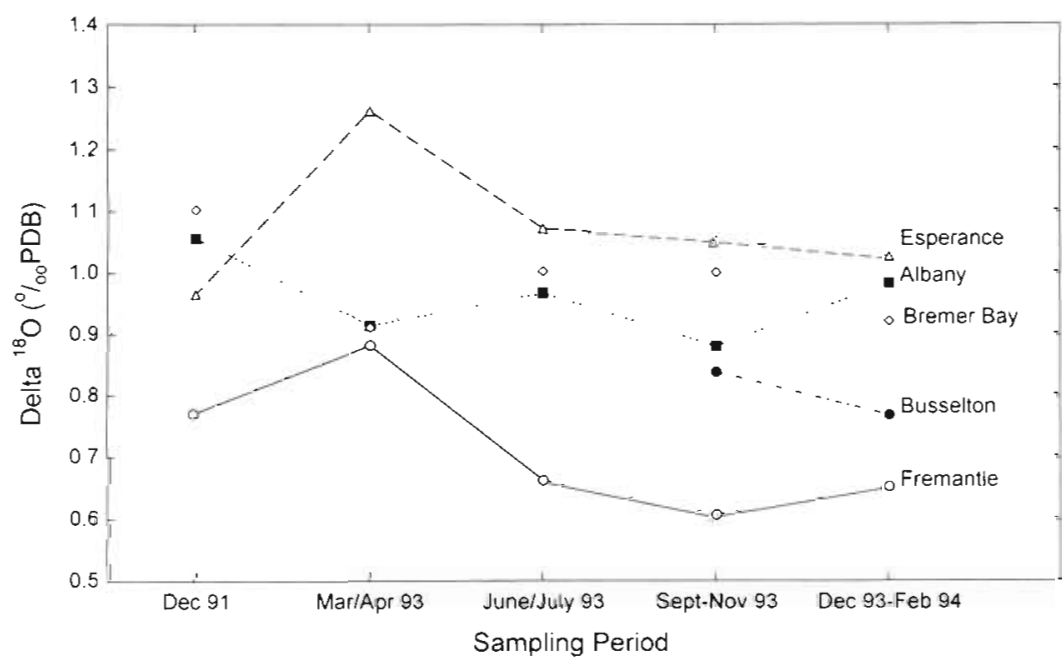

Fig. 6. Mean $\delta^{18} \mathrm{O}$ for each sampling period vs sampling period for each of the 5 locations

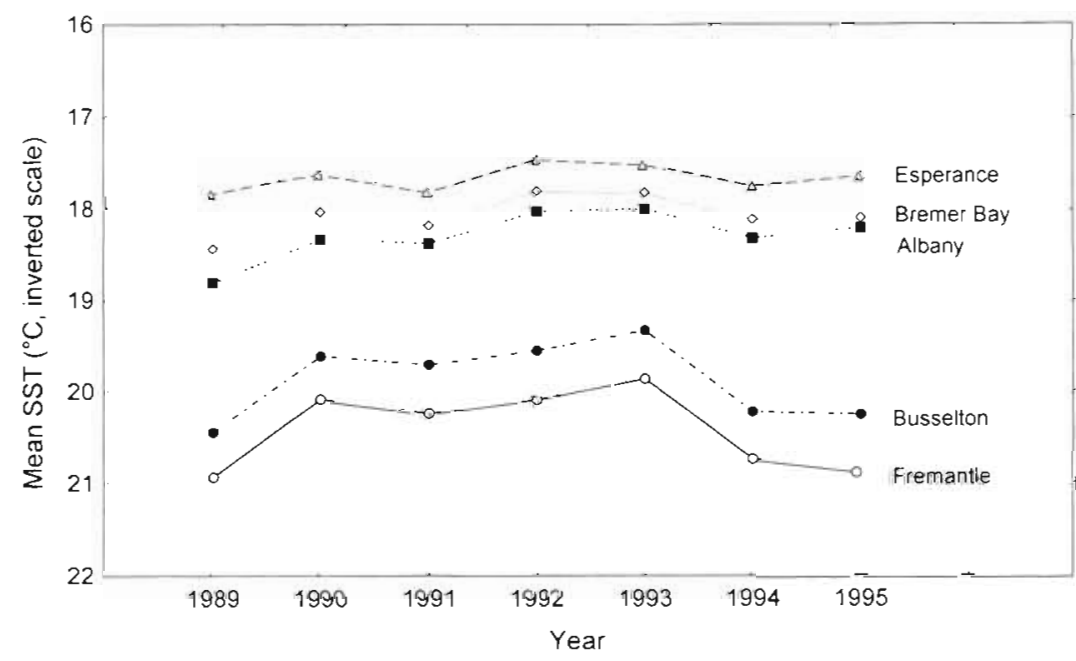

Fig. 7. Yearly mean sea surface temperatures vs year for each of the 5 locations. Sea surface temperature is plotted with an inverted scale to allow easy comparison of Figs. 6 \& 7 (see Reynolds \& Smith 1994)
Table 2. Sardinops sagax. ANCOVA for $\delta^{18} \mathrm{O}$ of otolith carbonate

\begin{tabular}{|lrrrrr|}
\hline Source & df & $\begin{array}{c}\text { Type III } \\
\text { SS }\end{array}$ & MS & F-value $\begin{array}{c}\text { Level of } \\
\text { significance }\end{array}$ \\
\hline Location & 4 & 6.32568 & 1.58142 & 69.79 & 0.0001 \\
Otolith weight & 1 & 1.11700 & 1.11700 & 49.30 & 0.0001 \\
Date & 4 & 0.62779 & 0.15695 & 6.93 & 0.0001 \\
Error & 392 & 8.88206 & 0.02266 & & \\
Total & 401 & 16.47358 & & & \\
\hline
\end{tabular}

Table 3. Sardinops sagax. ANCOVA for $\delta^{13} \mathrm{C}$ of otolith carbonate

\begin{tabular}{|lrrrrr|}
\hline Source & df & $\begin{array}{c}\text { Type III } \\
\text { SS }\end{array}$ & MS & F-value & $\begin{array}{c}\text { Level of } \\
\text { significance }\end{array}$ \\
\hline Location & 4 & 3.31165 & 0.82791 & 22.77 & 0.0001 \\
Otolith weight & 1 & 7.81031 & 7.81031 & 214.77 & 0.0001 \\
Date & 4 & 0.88165 & 0.22041 & 6.06 & 0.0001 \\
Error & 392 & 14.25558 & 0.03637 & & \\
Total & 401 & 25.67998 & & & \\
\hline
\end{tabular}


Western Australia are strong evidence that the stocks of adult fish studied were non-mixing and could be assumed to be separate units for some fisheries management purposes.

Obviously if fish were mixing over the whole area occupied by a species on a time scale that averaged out their isotope signatures, i.e. with each fish spending equal lengths of time in the whole range of temperatures that the species can be exposed to, they would all have similar signatures. If, however, they remained completely separated for most of their lives, with the bulk of otolith carbonate laid down within a single environment with its own characteristic temperature regime, then the oxygen isotope signatures would reflect that environment and the signatures for the different regions would be different. For species of fish that fall between these 2 extremes (of complete separation and total homogeneity) some smearing of the isotopic properties of the otoliths would be expected. Such species would be considered as being partially migratory or, at least, as occupying a home range large enough to overlap with other, different ranges of other individual fish of the same species. Such considerations can only be viewed in connection with the sampling regime: how close the sampling sites are to one another, how large an area is considered as a single site, and the timing of the sampling. In this study the sampling sites were far enough from each other for there to be a reasonable possibility that separate groups of fish were being tested, and sampling was carried out, as far as was possible, simultaneously at all locations for each sampling occasion to ensure that a 'snapshot' was obtained. Because of the small size of pilchard otoliths and the need to pool material from several fish to obtain enough for analysis, some information that might have been obtained from the analysis of otoliths from single fish (for example, indications of individual migrations) was not available.

The oxygen isotopic data presented here with sea surface temperature data (Reynolds \& Smith 1994) for the years during which the otoliths were likely forming allowed us to derive an empirical relationship $\left(\delta^{18} \mathrm{O}=\right.$ $3.2-0.12\left(T^{\circ} \mathrm{C}\right)$ for water temperature and $\delta^{13} \mathrm{O}$ as measured (Fig. 5). The similarity of the relationship between $\delta^{18} \mathrm{O}$ and temperature observed here to that reported for a compilation of all otolith data available from the literature $\left[\delta^{18} \mathrm{O}=3.58-0.196\left(T^{\circ} \mathrm{C}\right)\right.$; Kalish 1991b] might be taken to indicate that the populations of pilchards examined here were indeed separated for a period of time necessary for them to reflect rather precisely the temperature regime of their ambient water-further evidence that they could be assumed to be distinct, clearly defined, non-mixing stocks for those purposes of fisheries management not aimed at the genetic level.
The observation that variations in $\delta^{13} \mathrm{C}$ for pilchards were attributable more to otolith size than to location of capture of the fish is consistent with the hypothesis (Kalish $1991 \mathrm{~b}$ ) that $\delta^{13} \mathrm{C}$ is dependent to a large degree on metabolic rate, with higher rates resulting in greater depletion in otolith ${ }^{13} \mathrm{C}$. It is evident (Fig. 4) that lighter otoliths (generally from smaller fish) are more depleted in ${ }^{13} \mathrm{C}$ than heavier otoliths from larger fish. In addition, the entire group of pilchards examined in this study exhibited a range of $\delta^{13} \mathrm{C}$ from -7.57 to -6.16 with an approximate mean of -6.9 . These figures would warrant classifying the species as a whole as having a high metabolic rate (Kalish 1991b). This is as would be anticipated for a species of small, active, schooling pelagic fish. However, uncertainties in the underlying causes of variations in $\delta^{13} \mathrm{C}$ values have been highlighted in this study by the observation of significant differences between fish from Albany and Bremer Bay, whereas the similarity in temperature regimes at the 2 locations might well explain our failure to distinguish them on the basis of oxygen isotope ratios.

Although stable isotope ratios have been used before to distinguish migratory from non-migratory stocks of the New Zealand smelt (Nelson et al, 1989), this is the first report to our knowledge of the use of stable isotope ratios to delineate populations of a pelagic oceanic fish. The method might be usefully applied to problems of the population structure of any species where variations in water temperature across the geographical range of the species are adequate to ensure an expectation of measurable oxygen isotope ratio differences.

Acknowledgements. We are grateful to Mr S. Blight, Mr M Rossbach and Ms J. Moore for assistance and to Dr N. Caputi for advice on statistics. Stable isotope analyses were carried out by CSIRO Division of Water Resources (Dr J. V. Turner) and were paid for with a grant from the Australian Fisheries Research and Development Corporation (FRDC), whose help is gratefully acknowledged.

\section{LITERATURE CITED}

Caputi N, Fletcher WJ, Pearce A, Chubb CF (1996) Effect of the Leeuwin Current on the recruitment of fishes and invertebrates along the Western Australian coast. Mar Freshwat Res 47:147-155

Degens ET, Deuser WG, Haedrich RL (1969) Molecular structure and composition of fish otoliths. Mar Biol 2:105-113

Devereux I (1967) Temperature measurements from oxygen isotope ratios of fish otoliths. Science 155:1684-1685

Edmonds JS, Caputi N, Moran MJ, Fletcher WJ, Morita M (1995) Population discrimination by variation in concentrations of minor and trace elements in sagittae of two Western Australian teleosts. In: Secor DH, Dean JM, Campana SE (eds) Recent developments in fish otolith research. University of South Carolina Press, Columbia, p 655-670

Epstein S, Buchsbaum R, Lowenstam HA, Urey HC (1953) Revised carbonate-water isotopic temperature scale. Bull Geol Soc Am 64:1315-1326 
Fletcher WJ (1995) Application of the otolith weight-age relationship for the pilchard Sardinops sagax neopilchardus. Can J Fish Aquat Sci 52:657-664

Iacumin P, Bianucci G, Longinelli A (1992) Oxygen and carbon isotopic composition of fish otoliths. Mar Biol 113 $537-542$

Kalish JM (1991a) Oxygen and carbon stable isotopes in the otoliths of wild and laboratory-reared Australian salmon (Arripis trutta). Mar Biol 110:37-47

Kalish JM (1991b) ${ }^{13} \mathrm{C}$ and ${ }^{18} \mathrm{O}$ disequilibria in fish otoliths: metabolic and kinetic effects. Mar Ecol Prog Ser 75 $191-203$

This article was submitted to the editor
Mulcahy SA, Killingley JS, Phleger CF, Berger WH (1979) Isotopic composition of otoliths from a bentho-pelagic fish, Coryphaenoides acrolepsis, Macrouridae: Gadiformes. Oceanol Acta 2:423-427

Nelson CS, Northcote TG, Hendy CH (1989) Potential use of oxygen and carbon isotopic composition of otoliths to identify migratory and non-migratory stocks of the New Zealand common smelt: a pilot study. NZ J Mar Freshwat Res 23:337-344

Reynolds RW, Smith TM (1994) Improved global sea surface temperature analyses using optimum interpolation. $\mathrm{J} \mathrm{Cli-}$ mate 7:929-948

Manuscript first received: February 10, 1997 Revised version accepted: April 24, 1997 